\title{
A taxonomic summary and revision of Rozella (Cryptomycota)
}

\author{
Peter M. Letcher ${ }^{1}$ and Martha J. Powell ${ }^{1}$
}

1'Department of Biological Sciences, The University of Alabama, 1332 SEC, Box 870344, 300 Hackberry Lane, Tuscaloosa, AL 35487, USA; corresponding author e-mail: letch006@ua.edu

\begin{abstract}
Rozella is a genus of endoparasites of a broad range of hosts. Most species are known by their morphology and host specificity, while only three have been examined ultrastructurally and had portions of their genome sequenced. Determined in molecular phylogenies to be the earliest diverging lineage in kingdom Fungi, Rozella currently nests among an abundance of environmental sequences in phylum Cryptomycota, superphylum Opisthosporidia. Here we briefly summarize a history of Rozella, provide descriptions of all species, and include a key to the species of Rozella.
\end{abstract}

Key words: Rozellida Rozellomycota straminipilous fungi

Article info: Submitted: 18 September 2018; Accepted: 8 November 2018; Published: 16 November 2018.

\section{INTRODUCTION}

Rozella (Cornu 1872) is a genus currently consisting of 27 species of endobiotic, holocarpic, unwalled parasites of a variety of hosts in Oomycota (Heterokontophyta), the Fungi phyla Blastocladiomycota, Monoblepharidomycota, Chytridiomycota, and Basidiomycota, and the green alga Coleochaete (Charophyta). Cornu erected the genus to describe four species, which had in common: (1) a plasmodial thallus; (2) posteriorly uniflagellate zoospores (for three of the species) that escape through a circular opening that results from the dissolution of a papilla; and (3) the formation of spherical, thick walled resting spores with spiny ornamentations. Cornu's species were described as $R$. monoblepharidis polymorphae, $R$. rhipidii spinosi, $R$. apodyae brachynematis, and $R$. septigena; he did not hyphenate the names, but these are to be added (Art.23.1). These names were those used when the species were formally described, but Cornu (1872) interchanged long and short versions of the specific epithets in the text: monoblepharidis polymorphae and monoblepharidis, rhipidii spinosiand rhipidii, and apodyae brachynematis and apodyae. Dick (2001: 246) treated the long and short versions as alternative names, and stated that "the selected epithet is therefore determined by accepted usage" and pointed out that Fischer (1892), Minden (1915), Sparrow (1938), and Karling (1942b) had used the shorter versions, and he followed their choice, rather than the longer versions used by Sparrow (1960) or Karling (1977), "because the shorter version does not imply species specificity." We concur with this interpretation as that choice was first made in 1892, and use the shorter versions here; thus, the first three of Cornu's species are herein subsequently referred to as $R$. monoblepharidis, $R$. rhipidii, and $R$. apodyae.

No type species was designated. The first three species induced hypertrophy (swelling as a result of an increase in cell size) of the infected portion of the host, and each parasite thallus formed a single sporangium. The fourth-named species was distinguishable from the others by the absence (or slightness) of host hypertrophy and by the formation from the thallus of a linear series of sporangia that were separated from each other by cross walls. Thus, at conception, there were two morphologically distinct forms within Rozella, the "sporangium" (monosporangiate) form containing Cornu's first three species, and the "septigena" (polysporangiate) form containing $R$. septigena. Subsequently, the developmental distinction (monosporangiate vs polysporangiate) was regarded as important, such that Fischer (1892) erected the genus Pleolpidium for the monosporangiate members of Rozella, with $P$. monoblepharidis as the type species, and retained Rozella for the polysporangiate form, with $R$. septigena as the type species. Clements \& Shear (1931:234) reiterated $R$. septigena as the type species for Rozella.

Foust (1937) discovered a second polysporangiate species, R. allomycis. Following Foust's discovery, Sparrow (1938) stated a taxonomic issue: "The disposition of Cornu's $R$. septigena and $R$. allomycis Foust is dependent upon how inconclusively the genus is to be interpreted. If it [Rozella] is to be restricted to those species in which a single sporangium results from an infection, then [those] two species $[R$. septigena and $R$. allomycis] would be excluded and a new genus would have to be made for their accommodation." Sparrow (1938) and Karling (1942b) discussed in detail the taxonomic standing of Pleolpidium, and Sparrow (1938) treated Pleolpidium as a synonym of Rozella. A third polysporangiate species, $R$. achlyae, was discovered and described by Shanor (1942).

To accommodate the divergent morphology observed among Rozella species, Batko (1977) erected the generic name Skirgiellia to accommodate the three polysporangiate species, as S. achlyae, S. allomycis, and S. septigena (the

๑ 2018 International Mycological Association

You are free to share - to copy, distribute and transmit the work, under the following conditions:

Attribution: $\quad$ You must attribute the work in the manner specified by the author or licensor (but not in any way that suggests that they endorse you or your use of the work).

Non-commercial: $\quad$ You may not use this work for commercial purposes.

No derivative works: You may not alter, transform, or build upon this work.

For any reuse or distribution, you must make clear to others the license terms of this work, which can be found at http://creativecommons.org/licenses/by-nc-nd/3.0/legalcode. Any of the above conditions can be waived if you get permission from the copyright holder. Nothing in this license impairs or restricts the author's moral rights. 
type species). Rozella was retained for the monosporangiate forms. Batko (1977) suggested that another of Cornu's originally described species, $R$. monoblepharidis, supposedly "...the most common species in the New as well as the Old World, and the first one described by Cornu (in the sense of "page-priority") ... should be recognized as the type", but, as pointed out above, a type had already been selected and "page priority" is not a consideration in selection. Further, as Batko included the type of Rozella in his concept of Skirgiella, his generic name is illegitimate as it was nomenclaturally superfluous (Arts 52.1, 52.2). This also means that Doweld (2014)'s introduction of the family name Skirgielliaceae was also illegitmate as it was based on an illegitimate generic name (Art. 18.3); Doweld also validated two epithets of species first described invalidly in Rozella as they had lacked a Latin diagnosis, achlyae and allomycetis; the necessary nomenclatural corrections are provided below.

Currently, Rozella consists of 24 monosporangiate and three polysporangiate species. Held (1972a, b, 1973a, b, $1974,1975,1980,1981)$ provided seminal insights regarding the morphology, physiology, and ultrastructure of the polysporangiate $R$. allomycetis, and his observations served as a basis for later comparisons among other species. Recent investigations (Letcher et al. 2017, 2018) have revealed similar zoospore morphologies among monosporangiate and polysporangiate species, indicating that regardless of thallus morphology or host specificity, zoospore ultrastructure is quite similar.

The Rozella life-cycle has been described elsewhere, so can be summarized. When viewed with light microscopy, the zoospore is elongate, 1.2-2.2 $\mu \mathrm{m}$ diam (Fig. 1A), the size difference dependent upon species. Zoospores encyst and attach to the host thallus (Fig. 1B). In polysporangiate forms, the parasite induces host hyphae to produce septa, compartmentalizing the parasite plasmodia as they develop into unwalled sporangial plasmodia (Fig. 1C) or walled resting spores (Fig. 1D). In monosporangiate forms, the parasite induces host hypertrophy (Fig. 1E). At maturity, zoospores may or may not swarm in the sporangium before discharge, and may emerge as a mass and immediately disperse (Fig. $1 \mathrm{~F}-\mathrm{I})$. In electron microscopy, the zoospore (Fig. 2A-C) is sphaerical to elongate, 1.2-2.2 $\mu \mathrm{m}$ diam, with a helmet-shaped nucleus (Held 1975) that is anteriorly convex and posteriorly concave, located in the anterior end of the zoospore. In the $R$. rhizoclosmatii zoospore, a lattice composed of perpendicular rods, as shown by serial sections (Letcher et al. 2017) is appressed to the surface of the nucleus (Fig. 2D). Posterior to the nucleus is a single sphaerical mitochondrion nestled into the concave surface of the nucleus (Fig. $2 \mathrm{~A}-\mathrm{C}$ ). Posterior to the mitochondrion, a striated rhizoplast caps the kinetosome at the anterior end of the flagellum (Fig. 2B-C). The flagellum extends posteriorly from the kinetosome, through a cavity in the plasma membrane (Fig. $2 \mathrm{~A}-\mathrm{C}$ ). In the central region of the zoospore is a microbody-lipid globule complex (MLC) composed of one or more lipid globules, a microbody, and a backing membrane, and ribosomes are dispersed in the cytoplasm (Fig. 2A-C).

Motile zoospores are attracted to the host, round up, and then encyst (Fig. 2E-F). In infection by $R$. allomycetis, intact host cytoplasm of Allomyces is distinguishable by the presence of concentric bodies (Figs 2E, 5A, 6A). The cyst produces an appressorium that attaches to the host wall (Fig. 2E-I). An infection tube extends from the appressorium and penetrates the host cell wall (Fig. 2I). The host plasma membrane is pushed inward as the parasite protoplast is discharged through an opening in the infection tube. Empty cysts (Fig. 2E, H) eventually collapse (Fig. 2I). The parasite protoplast occupies a compartment within the host cytoplasm (Fig. 2E, $G, I)$, then enlarges into an unwalled sporangial plasmodium (Fig. 3A) or walled resting spore (Fig. 6). In sporangial plasmodium development, the plasmodium produces lobed extensions that phagocytize host cytoplasm (Figs 3B, 4A); often a vacuole occupies the center of the plasmodium (Figs $3 \mathrm{~B}, 4 \mathrm{~A}$ ). At maturity the multinucleate sporangial plasmodium (Figs 3B, 4A) becomes a zoosporangium that completely fills the host (Fig. 4B). Numerous zoospores are cleaved (Figs 4B, 5) and released through a discharge pore (Fig. $5 \mathrm{~B}$ ) or tube (Fig. 5C). In resting spore development, multiple plasmodia occupy a host compartment (Fig. 6A). Resting spore plasmodia are irregular in outline at first, but eventually become sphaerical (Fig. 6A), and resting spores of most Rozella species have spiny wall ornamentation (Fig. 6B).

Rozella has engendered much interest over the last decade, beginning with two strains in a molecular phylogeny that occurred as the earliest diverging lineage in the fungi (James et al. 2006). One strain (JEL 347, R. rhizoclosmatii) was monosporangiate, while the second (UCB 47-54, $R$. allomycetis) was polysporangiate. Subsequently, this lineage came to include not only the two strains of Rozella, but a myriad of novel small subunit ribosomal RNA gene sequences (SSU rRNA) derived from environmental surveys (e.g. Lara et al. 2010, Jones et al. 2011a, Karpov et al. 2014, Lazarus \& James 2015, Grossart et al. 2016, Rojas-Jimenez et al. 2017, Tedersoo et al. 2017). Initially referred to as the Rozella clade (James et al. 2006), then "Rozellida" (Lara et al. 2010), the lineage is now assigned to the Cryptomycota (Jones et al. 2011b), and more recently has been also referred to as Rozellomycota (e.g. Corsaro et al. 2014) and Rozellosporidia (Karpov et al. 2017). Because of the position of Cryptomycota in expanded molecular phylogenies, different schools of thought exist as to its actual affinity. James et al. (2013) proposed that Cryptomycota and Microsporidia share a common ancestor. Karpov et al. (2014) erected the superphylum Opisthosporidia to include three phyla: Cryptomycota, Aphelida, and Microsporidia. Opisthosporidia was considered sister to Fungi. More recently, Tedersoo et al. (2017) placed Aphelida as sister of Blastocladiomycota in kingdom Fungi, and Cryptomycota + Microsporidia as a lineage sister to Fungi. Bass et al. (2018), however, placed Cryptomycota as sister to Microsporidia. In this taxonomic summary we use the most current hierarchical taxonomic framework (Tedersoo et al. 2018). Obviously, much work remains to confirm the placement of Rozella and Cryptomycota.

There has been considerable confusion over names to be applied to these organisms, and here we aim to provide a comprehensive summary of the taxonomy and nomenclature of both the phylum and the genus Rozella based on the current International Code of Nomenclature for algae, fungi and plants (ICN; Turland et al. 2018). 


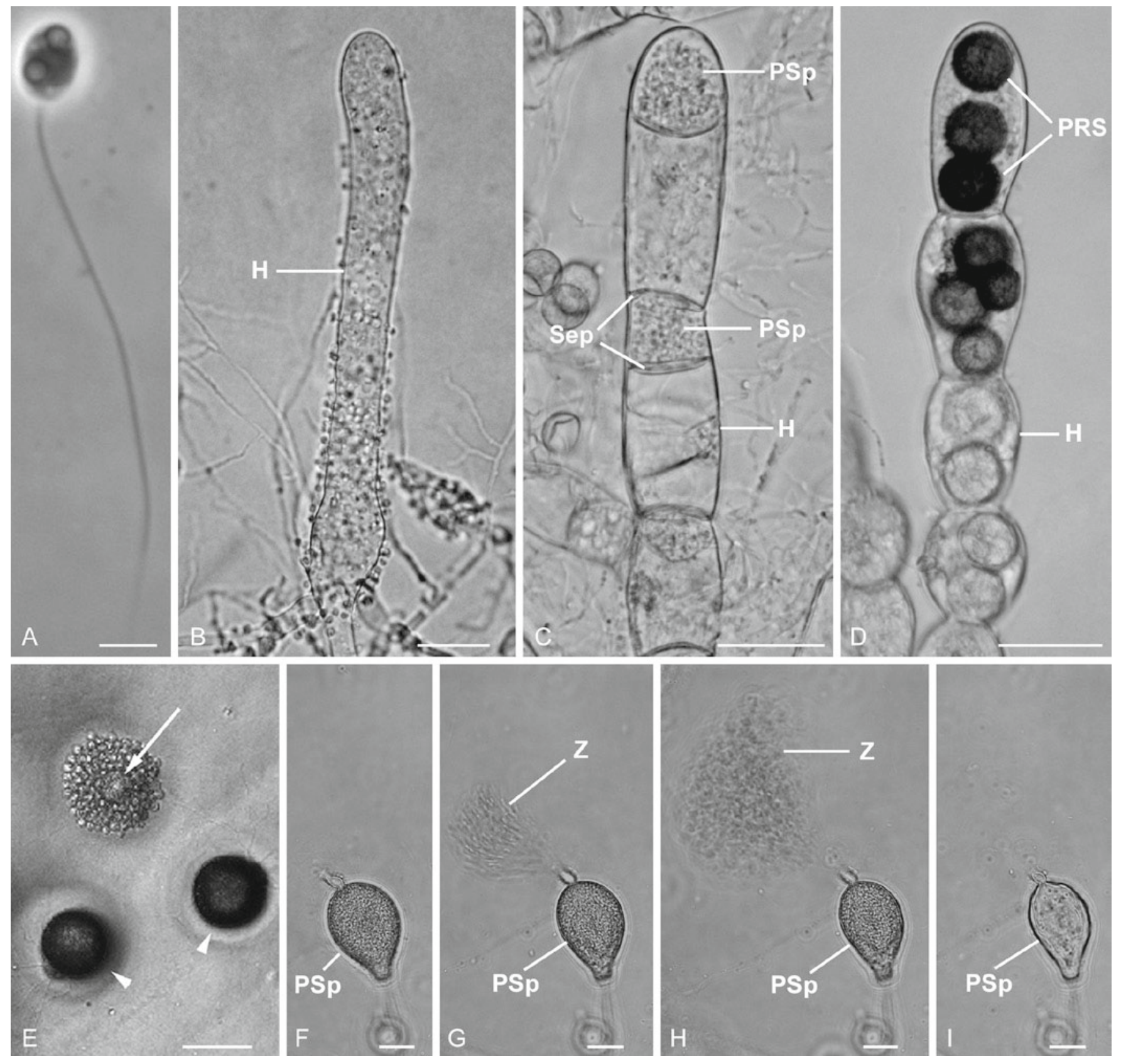

Fig. 1. Light microscopic images of Rozella. A. Motile zoospore of $R$. rhizoclosmatii [strain JEL 863, Letcher et al. 2017]. B-D. R. allomycetis and its host Allomyces macrogynus [strain UM690, unpubl.]. B. Encysted zoospores on host hypha. C. Parasite sporangia in septate segments of host hypha. D. Spiny parasite resting spores in septate segments of host hypha. E. Rozella rhizoclosmatii. Uninfected sporangium of host Rhizoclosmatium globosum, with discharged zoospores (arrow); infected, hypertrophied host sporangia (arrowheads) [strain JEL 863, Letcher et al. 2017]. F-I. Rozella multimorpha. Zoospore release from terminal sporangium in infected host Pythium catenulatum [strain JEL 883, unpublished; see Letcher et al. 2018]. Abbreviations: $C B$, concentric bodies; H, host; PSp, parasite sporangium; PRS, parasite resting spore; Sep, septum. Bars $A=1 \mu \mathrm{m}, B-D=15 \mu \mathrm{m}, E=100 \mu \mathrm{m}, F-I=10 \mu \mathrm{m}$.

\section{TAXONOMY}

The following taxonomic summary is based on our understanding and interpretation of these organisms. Additionally, without morphological, molecular, or ultrastructural evidence to the contrary, we include holocarpic, posteriorly uniflagellate Rozella species that previously have been excluded from the genus (Dick 2001).

SUPERGROUP: Opisthokonta Cavalier-Smith, in Rayner et al., Evol. Biol. Fungi: 344 (1987).
Circumscription emended by Cavalier-Smith \& Chao (1995) and Adl et al. (2005).

SuPERKINGDOM: Holomycota Y. Liu, BMC Evol. Biol. 9.272: 3 (2009). Synonym: Nucletmycea M.W. Brown, Mol. Biol. Evol,. 26: 2706 (2009).

KIngdom: Fungi R.T. Moore, Bot. Marina 23: 371 (1980).

Subkingdom: Rozellomyceta Tedersoo et al., Fungal Divers.: doi.org/10.1007/s13225-018-0401-0: 13 (2018). 

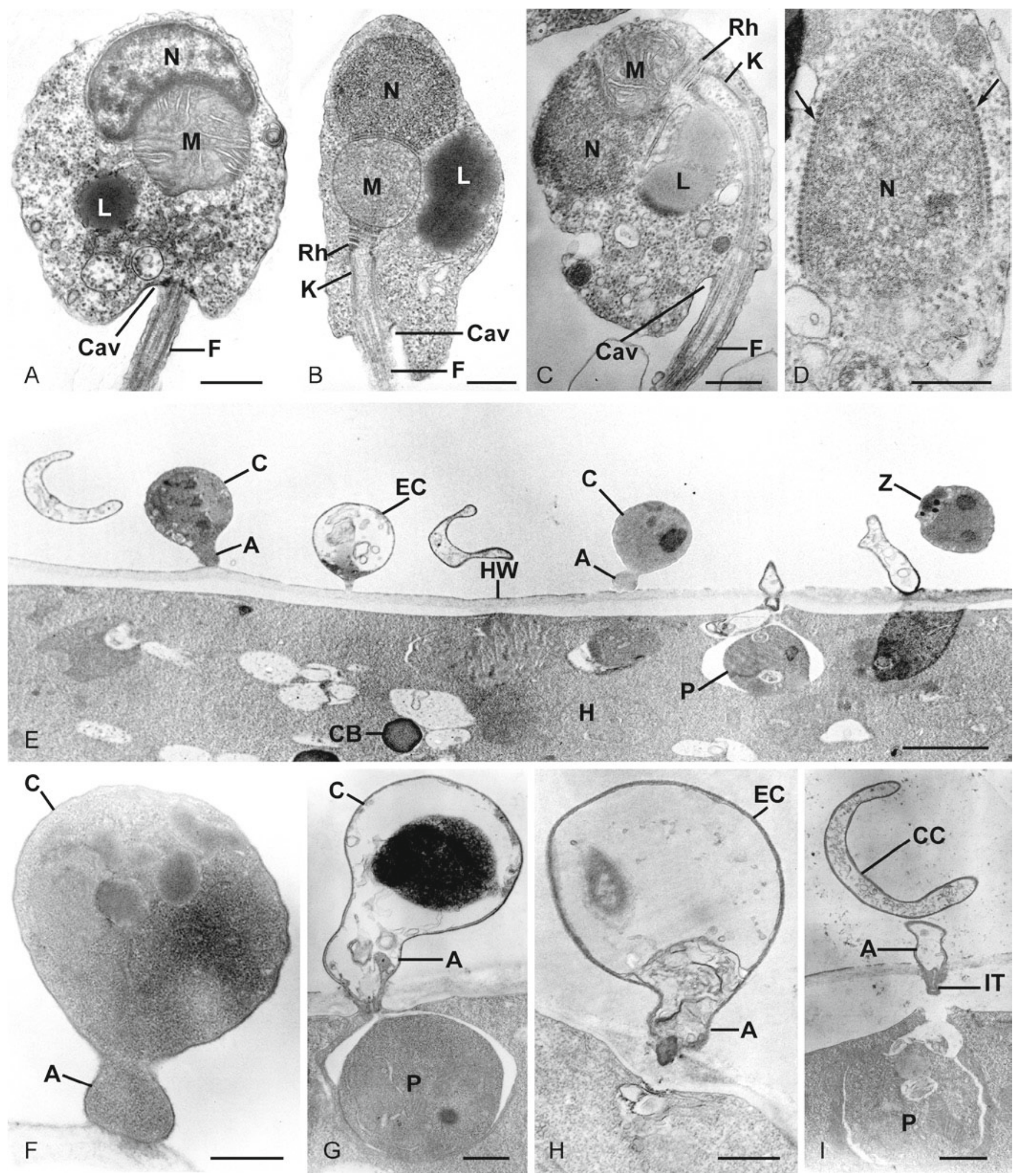

Fig. 2. Transmission electron microscopic images of Rozella zoospores and infection. A. R. allomycetis [strain CSF 55; Powell et al. 2017]. B. R.multimorpha [strain JEL 883; Letcher et al. 2018]. C-D. R. rhizoclosmatii [strain JEL 863; Letcher et al. 2017]. D. A lattice of perpendicular rods (arrows) about the nucleus. E-I. R. allomycetis [strain UM 690; Powell and Letcher, unpubl.] parasitizing Allomyces macrogynus. E. Early stages of infection. F. Encysted zoospore. G. Zoospore cyst and early infection. H. Empty zoospore cyst. I. Collapsed zoospore cyst and early parasite protoplast. Abbreviations: A, appressorium; C, zoospore cyst; Cav, posterior cavity; CB, concentric body; CC, collapsed zoospore cyst; $\mathrm{EC}$, empty zoospore cyst; F, flagellum; H, host; IT, infection tube; K, kinetosome; L, lipid globule; M, mitochondrion; N, nucleus; P, parasite; Rh, rhizoplast; Z, zoospore. Bars A, F-I $=0.5 \mu \mathrm{m}, \mathrm{B}-\mathrm{D}=0.25 \mu \mathrm{m}, \mathrm{E}=2 \mu \mathrm{m}$. 
Diagnosis: "Vegetative cells amoeboid, with pseudopodial extensions extending around host organelles; zoospores with a posterior flagellum that has a solid rhizoplast associated with a long kinetosome; one single large mitochondrion (missing in Microsporidea); resting spores thick-walled; chitinous wall present only in some life stages; penetration of host cells via germ tube; intracellular obligate parasites of fungi, animals and protists that consume host organelles via phagocytosis" (Tedersoo et al. 2018).

Type: Rozella Cornu 1872.

SUPERPHYLUM: Opisthosporidia Karpov et al., Frontiers Microbiol. 5: 8 (2014).

Phylum: Cryptomycota M.D.M. Jones \& T.A. Richards, IMA Fungus 2: 173 (2011).

Synonyms: Rozella clade, James et al., Mycologia 98: 863 (2006).

Rozellida Lara et al., Protist 161: 117 (2010).

Rozellomycota T.Y. James \& Berbee, BioEssays 34: 96 (2011); nom. inval. (Art. 36.1(a)); D. Corsaro \& R. Michel, Parasit. Res. 113: 1916 (2014); nom. inval. (Art. 36.1(a)).

Rozellomycota Doweld, Index Fung. 43: 1 (2013).

Rozellosporidia Karpov et al., J. Eukaryotic Microbiol. 64: 573 (2017).

Note: The circumscription was emended by Karpov \& Aleoshin (2014). The name was not validly published earlier in the year by Jones et al. (2011a). As the name is not based on that of an included genus, no type was required for valid publication (Art.10.10). The name was based on the cryptic nature of the majority of its inclusions, namely environmental sequences.

Subphylum: Rozellomycotina Tedersoo et al., Fungal Divers. doi.org/10.1007/s13225-018-0401-0: 13 (2018).

Diagnosis: As for subkingdom above.

Type: Rozella Cornu 1872.

Class: Microsporidia Corliss \& Levine, J. Protozool. 10: 26 (1963).

Genus: Rozella Cornu, Ann. Sci. Nat., Bot., sér. 5, 15: 148 (1872).

Synonyms: Skirgiellia A. Batko, Acta Mycol. 13: 321 (1977); nom. illegit. (Arts. 52.1, 52.2).

Rozia Cornu, Bull. Soc. Bot. France 19: 71 (1872); nom. illegit. (Art. 53.1); non Rozea Bescherelle, Mém. Soc. Sciences Nat. Cherbourg 16: 241 (1872); nec Rosea Fabr., Enum.: 47 (1759).

Pleolpidium A. Fischer, Rabenhorst's Kryptogamen-FI. 1: 43 (1892).

Type: Rozella septigena Cornu1872.

Note: Dick (2001) designated R. monoblepharidis as the type species of Rozella, on the justification that it was the firstnamed species (Cornu 1872), but that mechanical method is contrary to the Code (Arts 10.5, 10.6), and in any case Clements \& Shear (1931) had already selected a different one of the original species, $R$. septigena, and that must be followed (Art. 10.5) unless changed by conservation.

\section{THE SPECIES}

Rozella achlyae (Doweld) Letcher, comb. nov. MycoBank MB827617

Basionym: Skirgiellia achlyae Doweld, Index Fung. 129: 1 (2014).

Synonyms: Rozella achlyae Shanor, J. Elisha Mitchell Sci. Soc. 58: 100 (1942); nom. inval. (Arts. 39.1, 40.1).

Skirgiellia achlyae (Shanor) A. Batko, Acta Mycol. 13: 322 (1977); nom. inval. (Arts. 39.1, 40.1).

Type: Shanor (J. Elisha Mitchell Sci. Soc. 58: pl. 17, figs 1-7, 1942; lectotype designated here, MBT 384204).

Description: "An endotrophic parasite of Achlya flagellata causing very slight or no hypertrophy. Young plasmodium hardly distinguishable in the host protoplasm, hyaline and very nearly optically homogeneous. Sporangia formed in a linear sori, cylindrical to somewhat barrel shaped, length and width depending largely upon that of host hyphae; exit papillae short, about $1.5 \mu \mathrm{m}$ in length, rupturing following gelatinization of the tips. Zoospores swimming in a jerky and darting manner, ovoid, 2-3 $\times 3-4 \mu \mathrm{m}$ with a single refractive globule, single flagellum posteriorly attached, usually $12-15$ $\mu \mathrm{m}$ in length. Resting bodies produced in segments formed in host hyphae that resemble sporangial sori, each segment containing from one to many resting bodies. Resting bodies spherical to oval, 12-6-23.7 $\mu \mathrm{m}$ in diameter (not including spines), mostly 15.8-17.3 $\mu \mathrm{m}$, usually covered with fine tenuous spines which commonly measure about 1.6-2.3 $\mu \mathrm{m}$ in length, wall of mature resting bodies thick, reddish-brown to amber brown in color. Resting spore germination follows a dormant period and is accomplished by the formation of posteriorly uniflagellate zoospores which escape through an exit papilla" (Shanor 1942).

Hosts: Achlya flagellata, A. proliferoides, Dictyuchus anomalus, and D. monosporus (Johnson 1955) (Oomycota).

Rozella allomycetis (Doweld) Letcher, comb. nov. MycoBank MB827616

Basionym: Skirgiellia allomycetis Doweld, Index Fung. 129: 1 (2014); as "allomycis".

Synonym: Rozella allomycis Foust, J. Elisha Mitchell Sci. Soc. 53: 198 (1937); nom. inval.

(Arts. 39.1, 40.1).

Skirgiellia allomycis (Foust) A. Batko, Acta Mycol. 13: 322 (1977); nom. inval.

(Arts. 39.1, 40.1).

Rozella allomycetes Nabel, Arch. Mikrobiol. 10: 527 (1939); nom. inval. (Art. 38.1(a)).

Type: Foust (J. Elisha Mitchell Sci. Soc. 53: pl. 22, figs 1-7, pl. 23, figs 1-27, 1937; lectotype designated here, MBT 384205).

Description: "Fungus body parasitic within the distal parts of the hyphae of Allomyces. Sporangia first formed at the tips of the young host hyphae, usually $1-5$ in a row, in basipedal succession; usually barrel-shaped, but varying greatly in size 

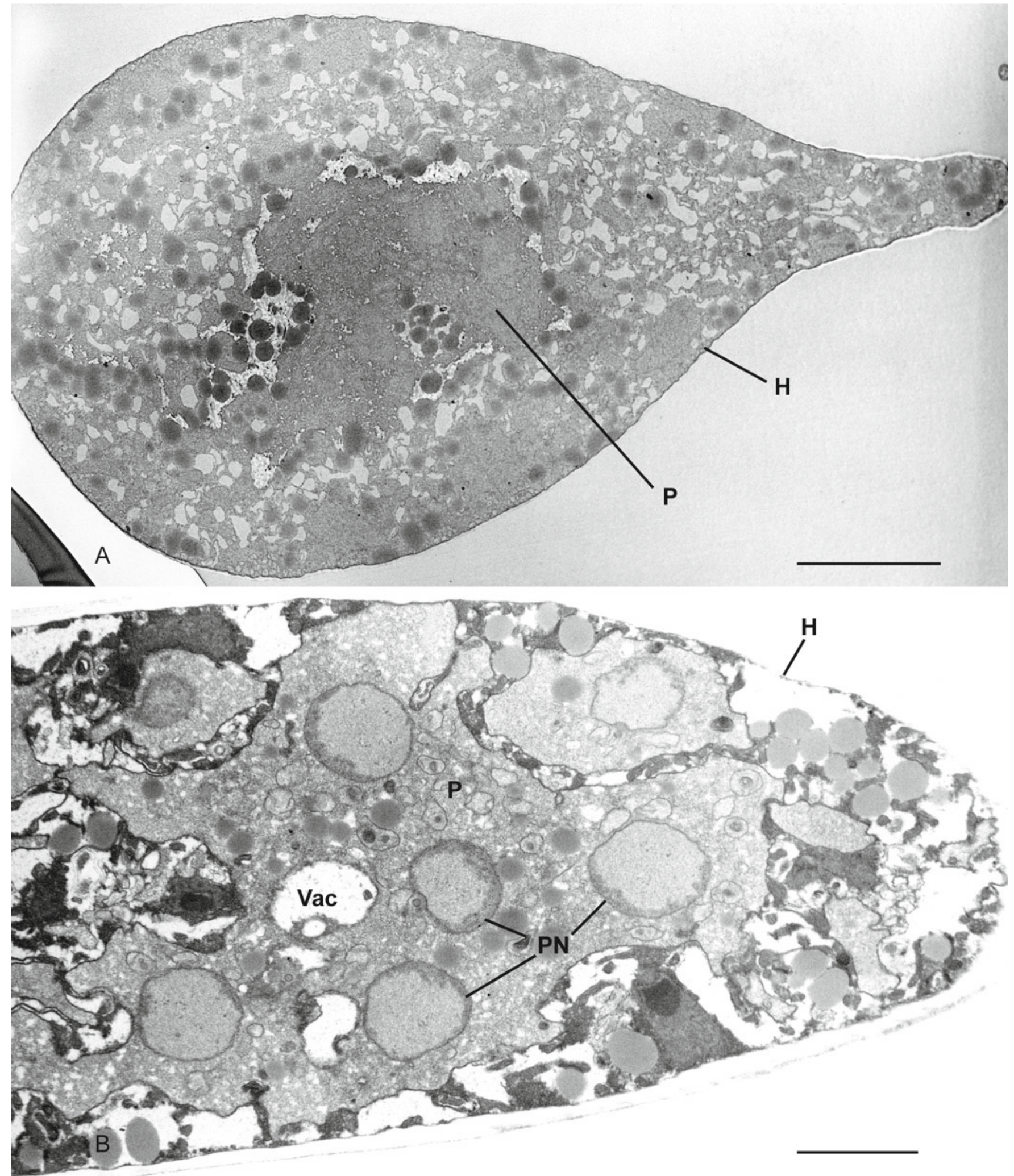

Fig. 3. Plasmodial development in Rozella. A. Early plasmodial formation of R. multimorpha [strain JEL 883; Letcher et al. 2018] in host Pythium catenulatum. B. Multinucleate plasmodium of $R$. allomycetis [strain CSF 55; Powell et al. 2017] in host Allomyces arbuscula; plasmodium has a central vacuole. Abbreviations: $\mathrm{H}$, host; $\mathrm{P}$, parasite plasmodium; PN, parasite nucleus; Vac, vacuole. Bars $=5 \mu \mathrm{m}$.

Fig. 4. Plasmodial development in Rozella. A. Multinucleate plasmodium of R. rhizoclosmatii [strain JEL 863; Letcher et al. 2017] in host Rhizoclosmatium globosum; plasmodium has a central vacuole. B. Early zoospore cleavage of $R$. allomycetis [strain CSF 55; Powell et al. 2017] in host Allomyces arbuscula; nuclei and mitochondria are organized and flagella appear in cleavage furrows. Abbreviations: F, flagella; PM, parasite mitochondrion; PN, parasite nucleus; Vac, vacuole. Bars $=1 \mu \mathrm{m}$. 


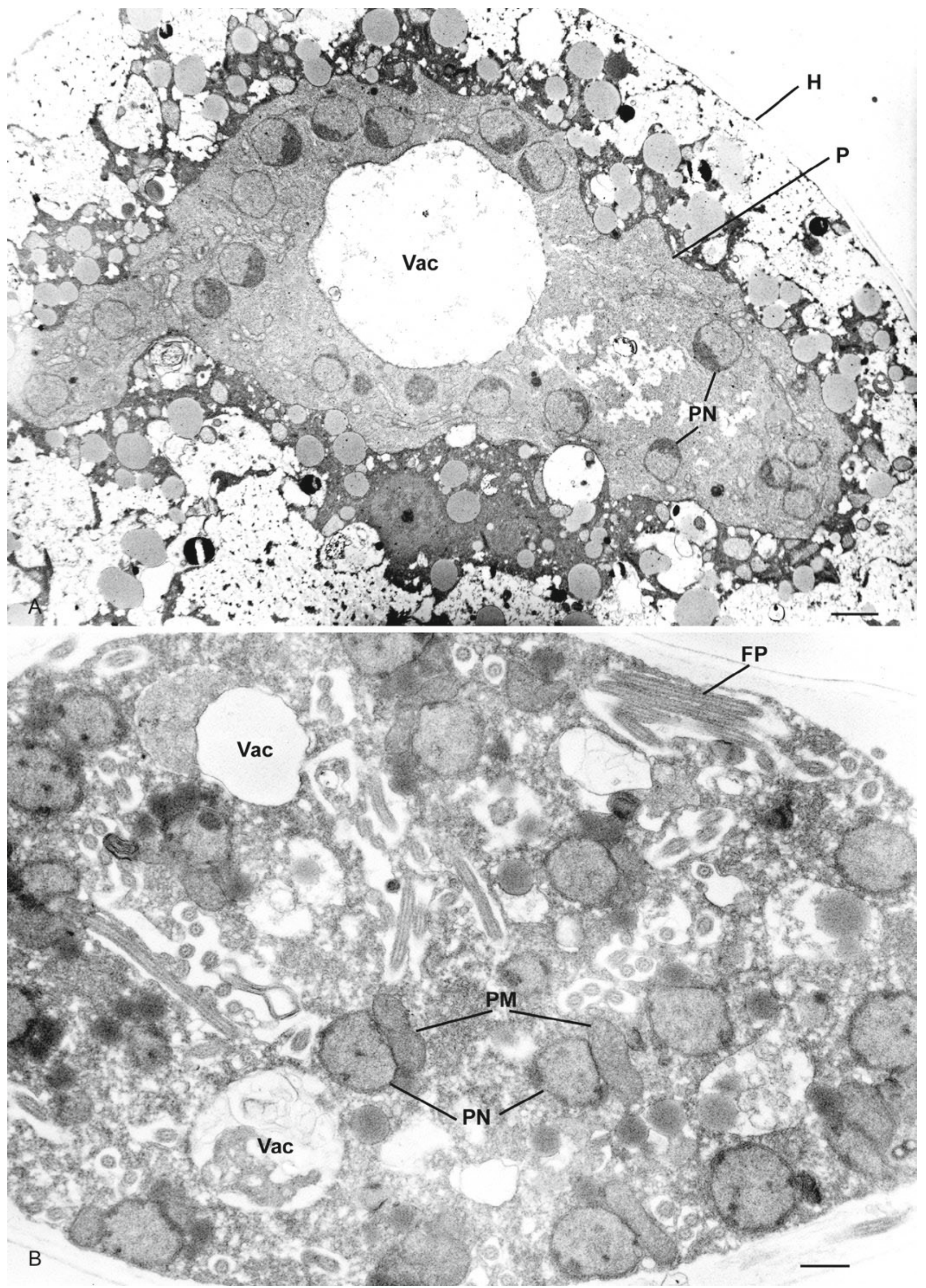



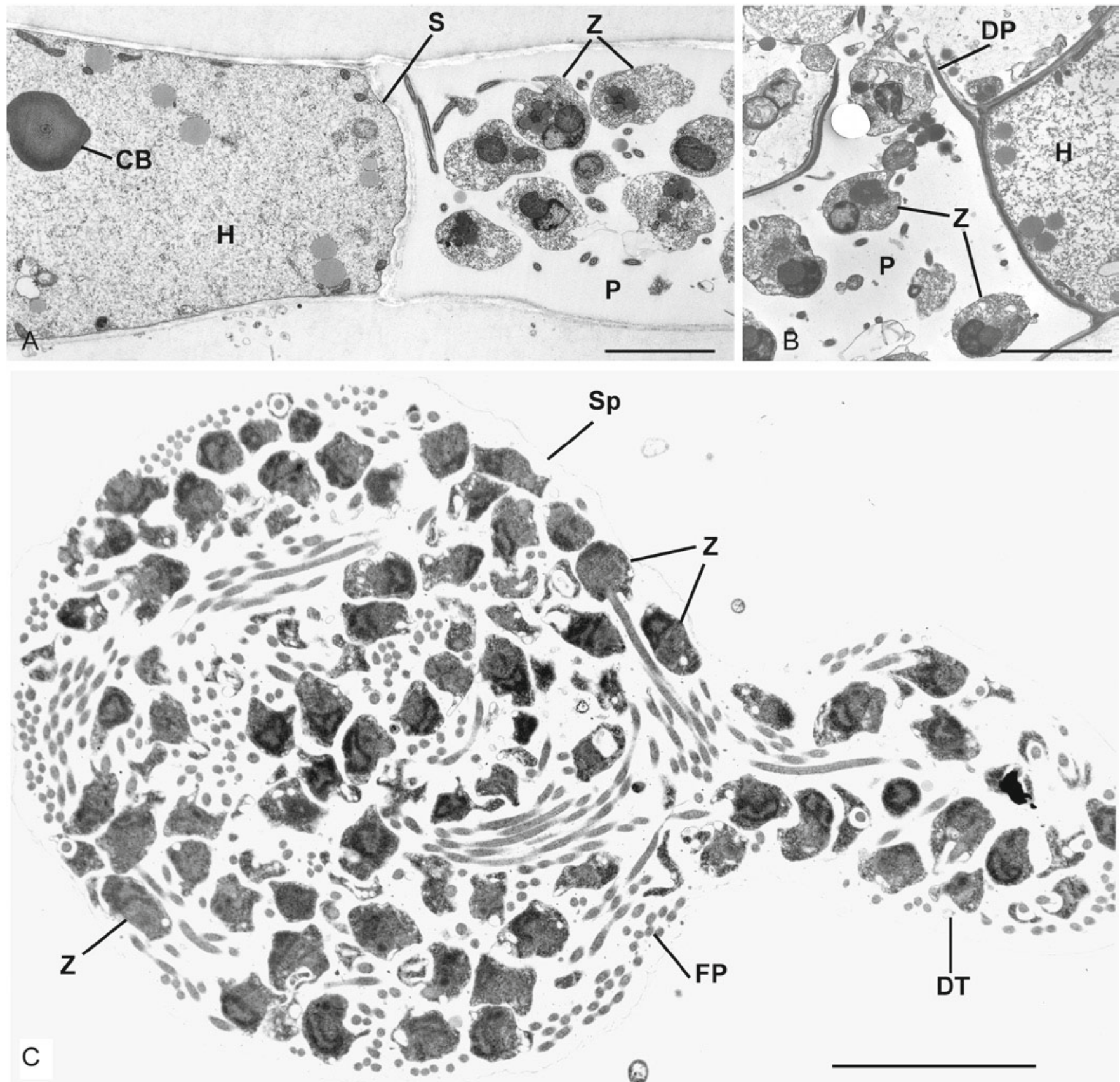

Fig. 5. Completed zoospore formation in Rozella. A. Zoospores of R. allomycetis [strain CSF 55; Powell et al. 2017] in host Allomyces arbuscula; septum separating host from parasite was induced by parasite. B. Zoospores of $R$. allomycetis [strain CSF 55] being released through a discharge pore. C. Zoospores of R. multimorpha [strain JEL 883; Letcher et al. 2018] in host Pythium catenulatum; some spores are in the discharge tube. Abbreviations: CB, concentric body; DP, discharge pore; DT, discharge tube; FP, flagellar pool; H, host; P, parasite; S, septum; Sp, sporangium; Z, zoospore. Bars $=5 \mu \mathrm{m}$.

and shape, $12-20 \times 20-40 \mu \mathrm{m}$, more often about $15.9 \mu \mathrm{m}$ $\times 24.6 \mu \mathrm{m}$. The wall apparently confined to the original host wall. Usually with one exit papilla, which is about $1.3 \mu \mathrm{m}$ long. Frequently a primary sporangium may be divided by one or more partitions into several smaller sporangia. Zoospores ovoid, the posterior end the larger, about 3-4 $\mu \mathrm{m}$ thick, containing one refractive globule and with one posteriorly attached flagellum, which is four times the length of the spore and is directed backward when the spore swims. Swimming by darting about with frequent changes of direction as typical for chytrid spores. The swimming period lasting about an hour, after which the spores germinate or die. Resting bodies formed later than the sporangia, occurring in the distal part of the host hyphae just behind the sporangia in swollen segments that are 1-35 in number, each segment containing from 1-16 resting bodies, the average being about 3 or 4 . Segments spherical, barrel-shaped, nearly cylindrical, or irregular, $20-40 \times 20-70 \mu \mathrm{m}$. Segments not completely filled by resting bodies, usually containing some left-over, dead, granular, host protoplasm. Resting bodies with spiny walls, spherical, 12-20 $\mu \mathrm{m}$ thick, averaging about $15.9 \mu \mathrm{m}$ thick (average of 20 measurements) counting the spines which are about $1.3 \mu \mathrm{m}$ long; yellowish brown to reddish brown in color; when mature with a thick $(.5 \mu \mathrm{m})$ wall, with a central 

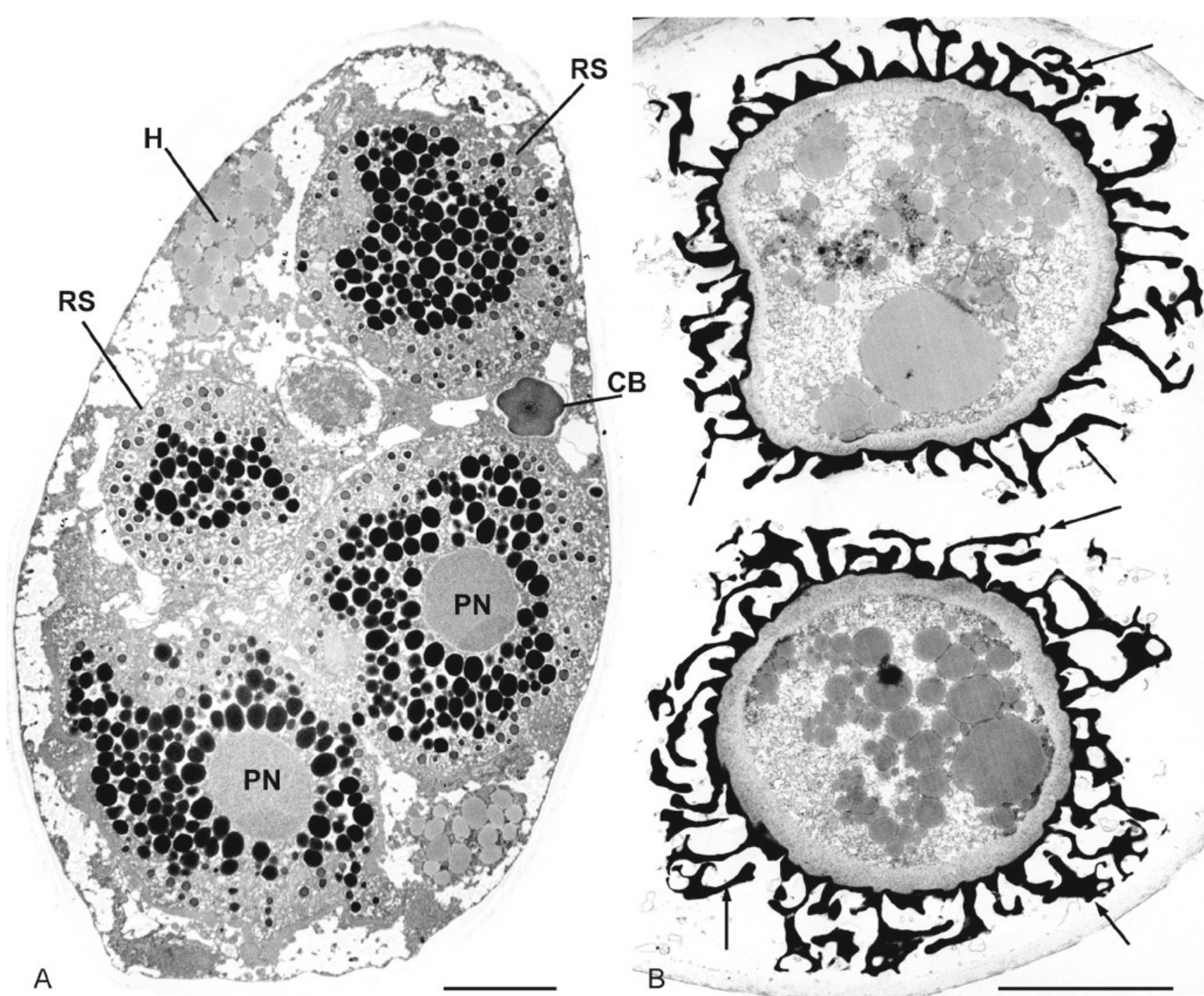

Fig. 6. Resting spores of Rozella allomycetis [strain CSF 55; Powell et al. 2017] in host Allomyces arbuscula. A. Resting spore formation. B. Sections through mature resting spores; arrows indicate resting spore wall ornamentation. Abbreviations: $\mathrm{CB}$, concentric body; $\mathrm{H}$, host; $\mathrm{PN}$, parasite nucleus; RS, resting spore. Bars $=5 \mu \mathrm{m}$.

hyaline globose mass of material surrounded by a granular zone of protoplasm. Germinating after a rest period of a week to form zoospores if fresh water is added and a young culture of Allomyces is present. The resting bodies may retain their vitality either dry or wet for several weeks, perhaps months. Zoospores from resting bodies identical with those from regular sporangia and capable of infecting young host hyphae" (Foust 1937).

Hosts: Allomyces arbuscula, A. javanicus, A. macrogynus, and $A$. anomalus (Blastocladiomycota).

Notes: Ultrastructure of the host-parasite interface between $R$. allomycetis and Allomyces anomalus has been studied (Powell et al. 2017), as has been ultrastructure of early infection stages of $R$. allomycetis in A. macrogynus (Powell \& Letcher, unpubl.). Foust's epithet "allomycis" was corrected to "allomycetis" by Doweld (2014), as the correct genitive case of the host genus Allomyces. Sparrow (1960) noted that Rozella allomycetes was "A name unaccompanied by a description. Probably referable to Rozella allomycis Foust".
Rozella apodyae Cornu, Ann. Sci. Nat., Bot., sér. 5, 15: 161 (1872).

Synonyms: Rozella apodyae-brachynematis Cornu, Ann. Sci. Nat., Bot., sér. 5, 15: 161 (1872).

Rozella apodachlyae M.W. Dick, Stramin. Fungi: 373 (2001); as "M. Cornu"; nom. illegit. (Art. 52.1).

Pleolpidium apodyae-brachynematis (Cornu) A. Fischer, Rabenh. Krypt.-FI. 1 (4): 45 (1892); as "apodyae".

Type: Cornu (Ann. Sci. Nat., Bot., sér. 5, 15: pl. 5, figs 10-14, 1872; lectotype designated by Dick 2001: 373).

Description: "Sporangium filling the sporangium of the host and assuming its shape, with a small apical papilla; zoospores somewhat elongate, with a posterior flagellum, escaping through a small pore resulting from the dissolution of the papilla; resting spore formed in the sporangium of the host, spherical, somewhat thick-walled, brownish (?), covered with very short tenuous spines" (Sparrow 1960).

Host: Apodachlya brachynema (Oomycota). 


\section{Rozella blastocladiae (Minden) Sparrow, Mycologia} 30: 377 (1938).

Basionym: Pleolpidium blastocladiae Minden, Krypt. Fl. Mark Brandenb. 5 (3): 253 (1911) ["1915"].

Type: Petersen (Bot. Tidsskrift 29 (4): 424, fig. 26c-d, 1909; neotype (as "lectotype") designated by Dick 2001: 374).

Description: "Sporangium assuming the shape of the hypertrophied host sporangium, which becomes somewhat broader and more ovoid than normal, with an apical pore, collapsing after discharge of the zoospores; zoospores not observed; resting spore exactly spherical, brown, thickwalled, the exospore densely covered with tenuous spines, germination not observed" (Sparrow 1960).

Hosts: Blastocladia pringsheimii, and B. gracilis (Blastocladiomycota).

Rozella canterae Sparrow, Aquatic Phycom., $2^{\text {nd }} e d n$ : 172 (1960).

Type: Canter (Trans. Brit. Mycol. Soc. 33: 357, fig. 3g-n; pl. 29, figs 4-5, 1950; lectotype designated by Dick 2001: 375).

Description: "Sporangium assuming the shape of the unhypertrophied host sporangium and completely filling it; zoospores ovoid, with a small refractive anterior globule and posterior flagellum, escaping after the operculum of the host is dehisced; resting spore somewhat ovoid, with a thick wall, the outer wall of which bears hexagonal ridges and spines" (Canter 1950, Sparrow 1960).

\section{Host: Chytridium oedogonii (Chytridiomycota).}

Rozella chytriomycetis Karling, Mycologia 38: 107 (1946); as "chytriomycii".

Type: Karling (Mycologia 38: 104, figs 9-19, 1946; lectotype designated by Dick 2001: 375).

Description: "Sporangia solitary, hyaline, filling host cell and conforming with the latter in size and shape, usually spherical, $10-40 \mu \mathrm{m}$, with one to three exit papillae... zoospores hyaline, oblong or slightly clavate, $3 \mu \mathrm{m} \times 1.5 \mu \mathrm{m}$, with a minute, $0.5-0.7 \mu \mathrm{m}$ refractive globule; swirling in sporangium before emerging; darting about rapidly in swimming, rarely becoming amoeboid. Resting spores partly or almost completely filling host cell, oval or spherical, $7-20 \mu \mathrm{m}$, with large central vacuole, usually coarsely granular cytoplasm; wall dark brown, rarely smooth, usually spiny or echinulate; germination unknown" (Karling 1946).

Host: Chytriomyces hyalinus (Chytridiomycota).

Rozella cladochytrii Karling, Torreya 41: 105 (1941).

Type: Karling (Amer. J. Bot. 29: 26, figs. 1-24, 1942; lectotype designated here, MBT 384206).
Description: "Sporangia solitary in host cell, spherical, 10-40 $\mu \mathrm{m}$, ovoid, ellipsoid, 10-15 $\mu \mathrm{m} \times 15-35 \mu \mathrm{m}$, pyriform, and obclavate, hyaline and smooth with one to three exit papillae; zoospores obclavate, $3.3-5 \mu \mathrm{m} \times 1.8-2 \mu \mathrm{m}$, aguttulate; flagellum $14 \mu \mathrm{m}$ long; emerging fully formed in a stream from the exit papillae and becoming actively motile in a few seconds. Resting spore faintly yellow, oval, spherical, 8-22 $\mu \mathrm{m}$, with a large central vacuole and coarsely granular cytoplasm; wall 1-1.8 $\mu \mathrm{m}$ thick, smooth or spiny, spines 1.5-3 $\mu \mathrm{m}$ long; transformed directly into a zoosporangium in germination and forming zoospores" (Karling 1942a).

Hosts: Nowakowskiella profusum, N. elegans, N. ramosum, Cladochytrium replicatum, C. crassum, and C. hyalinum (Chytridiomycota).

Note: The original description (Karling 1941) lacked illustrations, thus the species is neotypified by illustrations from a later work (Karling 1942) by the same author.

Rozella coleochaetes Sparrow, Papers Mich. Acad. Sci. Arts Letters 50: 118 (1965); as "coleochaetis".

Synonym: Plasmophagus coleochaetis (Sparrow) M.W. Dick, Straminip. Fungi: 451 (2001).

Type: Sparrow (Papers Mich. Acad. Sci. Arts Letters 50: 116, figs A-E, 1965; lectotype designated here, MBT 384207).

Description: "Sporangium completely filling the greatly enlarged host cell, spherical, 35-38 $\mu \mathrm{m}$, subspherical, $40-42$ $\times 33-40 \mu \mathrm{m}$, or clavate, $55 \times 15-25 \mu \mathrm{m}$, with a single strongly protruding discharge papilla $10 \mu \mathrm{m}$ in diameter. Zoospores numerous, 6-7 $\times 2-2.5 \mu \mathrm{m}$, fusiform, with a minute globule, motile within the sporangium, escaping through a sessile pore upon deliquescence of the papilla. Resting spore not observed" (Sparrow et al. 1965).

Host: Coleochaete (Charophyta).

Note: Blackwell et al. (2016) justified the exclusion of $R$. coleochaetes from the genus Plasmophagus.

Rozella cuculus (E. J. Butler) Sparrow, Mycologia 30: 377 (1938).

Basionym: Pleolpidium cuculus E. J. Butler, Mem. Dept. Agric. India, Bot. Ser. 1: 125 (1907).

Type: Butler (Mem. Dept. Agric. India, Bot. Ser. 1: plate VII, figs 22-25, 1907; lectotype designated by Dick 2001: 374).

Description: "Sporangium spherical, subspherical, or pyriform, formed in the sporangium of the host or in pronounced intercalary swellings of the hyphae, 19.2-24 $\mu \mathrm{m}$ in diameter, with a single papilla; zoospores obclavate, clavate, or ovoid, the flagellum emerging from the broader end; resting spore spherical, single, free in the sporangium or intercalary swelling of the host, $12-18 \mu \mathrm{m}$ in diameter, with a smooth pale-yellow somewhat thickened wall, germination not observed" (Sparrow 1960). 
Hosts: Pythium intermedium, and P. monospermum (Oomycota).

Note: Sparrow (1960) putatively included Pleolpidium tuberculorum Vuillemin (1909) and Chytridium simulans Dangeard (1896-97) as referable to $R$. cuculus.

\section{Rozella diplophlyctidis Karling, Nova Hedwigia 45: 529 (1987).}

Type: Karling (Nova Hedwigia 45: 534, figs 1-6, 1987 holotype).

Description: "Sporangia filling the host sporangia, spherical to subspherical, $18-28 \mu \mathrm{m}$ diameter, $\ldots$ and $1-4$ exit papillae. Zoospores ovoid to slightly elongate, 1.8-2.5 $\mu \mathrm{m}$ diameter, with a small hyaline refractive globule. Resting spores partly filling host cell, spherical, 16-22 $\mu \mathrm{m}$, with a brown spiny wall. Germination unknown" (Karling 1987).

Host: Diplophlyctis intestina (Chytridiomycota).

Rozella endochytrii Karling, Torreya 41: 106 (1941).

Type: Karling (Amer. J. Bot. 29: 30, figs 25-35, 1942; neotype designated here, MBT 384208).

Description: "Sporangia solitary in a host cell, spherical, 15$200 \mu \mathrm{m}$, oval, elongate, pyriform and irregular, depending on the size and shape of the host cell; wall of the sporangium hyaline and smooth with one to several exit papillae, 2-6 $\mu \mathrm{m}$ high. Zoospores obclavate, 3.4-4 $\mu \mathrm{m} \times 1.5 \mu \mathrm{m}$, aguttulate but with optically denser apical and basal regions which give them a characteristic appearance; swirling in the sporangium before dehiscence; emerging in a stream and becoming actively motile in a few seconds. Resting spores unknown" (Karling 1942a).

Host: Endochytrium operculatum (Chytridiomycota).

Note: The original description (Karling 1941) lacked illustrations, so the species is lectotypified by illustrations from a later work (Karling 1942) by the same author, of the original material.

Rozella irregularis (E. J. Butler) Sparrow, Mycologia 30: 377 (1938).

Synonym: Pleolpidium irregulare E. J. Butler, Mem. Dept. Agric. India, Bot. Ser. 1: 123 (1907).

Type: Butler (Mem. Dept. Agric. India, Bot. Ser. 1: pl. VIII, figs 1-12, 1907; lectotype designated by Dick 2001: 374).

Description: "Sporangia formed in the hyphae of the host, irregular in shape, terminal and intercalary, averaging $23 \mu \mathrm{m}$ in diameter, with a single papilla; zoospores obclavate, with a single cilium borne posteriorly, [resting] spores single, free in the cavity of the host-filament which is enlarged to contain them, numerous, $11-15 \mu \mathrm{m}$ in diameter, spherical, of pale yellow color, with a moderately thick wall, provided with short regular spines, germination not observed" (Butler 1907).
Hosts: Pythium (?) vexans, and Pythium sp. (Oomycota).

Note: Karling (1981) observed a species he tentatively identified as $R$. irregularis in Pythium debaryanum, and on the basis of his observations and those of others (Butler 1907, Shen \& Siang 1948), he expanded the diagnosis of the species.

Rozella itersoniliae D. J. S. Barr \& Bandoni, Mycologia 71: 1261 (1979).

Synonym: Pleotrachelus itersoniliae (D. J. S. Barr \& Bandoni) M. W. Dick, Stramin. Fungi: 453 (2001).

Type: Barr \& Bandoni (Mycologia 71: 1262, figs 1-4, 1979; - holotype).

Description: "Sporangium endobiotic with no definite wall. Zoospores globose, 2.0-2.5 $\mu \mathrm{m}$ diameter, posteriorly uniflagellate; whiplash flagellum 11-13 $\mu \mathrm{m}$ long. Resting spores not seen" (Barr \& Bandoni 1979).

Host: Itersonilia perplexans (Basidiomycota).

Rozella laevis Karling ex Letcher, sp. nov. MycoBank MB828495

Synonym: Rozella laevis Karling, Mycologia 34: 201 (1942); nom. inval. (Arts. 39.1, 40.1).

Type: Karling (Mycologia 36: 642, figs 1-19, 1944 - holotype).

Description: "Sporangium solitary, partly or completely filling hypertrophied portions of the host hyphae, variable in size and shape, spherical, 20-52 $\mu \mathrm{m}$, clavate, 10-20 $\mu \mathrm{m} \times$ 30-112 $\mu \mathrm{m}$, broadly and elongately pyriform with 1 to 3 exit papillae, 3-4 $\mu \mathrm{m}$ in diameter, by $2-3 \mu \mathrm{m}$ in height. Zoospores hyaline, with a globular spot that is not markedly refractive, obclavate to pyriform, $1.5-1.8 \mu \mathrm{m} \times 2.9-3.3 \mu \mathrm{m} ;$... flagellum $10-12 \mu \mathrm{m}$ long. Resting spores spherical, 11-18 $\mu \mathrm{m}$, oval, elongate or obpyriform with a large central vacuole and coarsely granular cytoplasm; wall smooth and hyaline, 1.5-2 $\mu \mathrm{m}$ thick; germination unknown" (Karling 1942b).

Hosts: Pythium gracile, and Pythium sp. (Oomycota).

Note: The original description (Karling 1942) lacked illustrations, so the species is typified by illustrations from a later work (Karling 1944) by the same author.

\section{Rozella longicollis Karling, Sydowia 19: 218 (1965).}

Type: Karling (Sydowia 19: pl. XLVI, figs 21-29, 1965; lectotype designated by Dick 2001: 375).

Description: "Sporangia solitary, filling the host sporangia, spherical, 20-60 $\mu \mathrm{m}$ diameter, pyriform, ovoid, 15-18 $\times 22-$ $35 \mu \mathrm{m}$, with 1-5 straight or curved exit tubes, $7-15 \mu \mathrm{m}$ long by 3-3.7 $\mu \mathrm{m}$ diameter, which project beyond surface of host cell. Zoospores broadly pyriform while motile, 1.5-2 × 2.5-3 $\mu \mathrm{m}$, with a slightly tapering anterior end and a minute dense body in the cytoplasm; flagellum 12-14 $\mu \mathrm{m}$ long; swirling in 
the sporangium before emerging. Resting spores filling only a portion of host cell, dark-brown, ovoid to spherical, 12-17 $\mu \mathrm{m}$ diameter, wall punctate to spiny, rarely smooth; germination unknown" (Karling 1965).

\section{Host: Pythium sp. (Oomycota).}

Rozella longisporangia Willoughby \& E. Rigg, Nova Hedwigia 37: 378 (1983).

Type: Willoughby \& Rigg, Nova Hedwigia 37: 377, fig. 1, 1983; lectotype designated here, MBT 384209).

Description: "Sporangia spherical, single, 15.2-42.2 $\mu \mathrm{m}$ diameter, or fused in pairs, or cymbiform, 50-72 $\mu \mathrm{m}$ long $\times$ 10-21 $\mu \mathrm{m}$ wide, or spherical with cylindrical extensions up to $53 \mu \mathrm{m}$ long $\times 5.3-7 \mu \mathrm{m}$ wide, or cylindrical only, up to 170 $\times$ 5.3-7 $\mu \mathrm{m}$. Sporangia with 1-4 dehiscence papillae, 3.8$6.8 \mu \mathrm{m}$ across. Zoospores liberated following liquefaction of the papillae. Zoospores swarm together in the sporangium before they disperse. Zoospores with hyaline oil drops, with a posterior flagellum 10.6-11.4 $\mu \mathrm{m}$ long, ovoid when in motion, spherical when at rest, 3-4 $\mu \mathrm{m}$ diameter. Resting spores not observed" (Willoughby \& Rigg 1983).

Host: Pythium oligandrum (Oomycota).

Rozella marina (Sparrow) Sparrow, Mycologia 30: 377 (1938).

Basionym: Pleolpidium marinum Sparrow, Biol. Bull. Mar. Biol. Lab. Woods Hole 70: 256 (1936).

Type: Sparrow (Biol. Bull. Mar. Biol. Lab. Woods Hole 70: figs 32-33, 1936; lectotype designated here, MBT 384211).

Description: "Sporangium spherical, completely filling the enlarged host sporangium, $30-45 \mu \mathrm{m}$ in diameter, at maturity forming from one to three pores, through which the zoospores are discharged; zoospores ellipsoidal, $3 \mu \mathrm{m}$ long by $2 \mu \mathrm{m}$ in diameter, posteriorly uniflagellate, without globules; resting spore not observed" (Sparrow 1960).

Host: Algochytrops polysiphoniae (Chytridiomycota).

Note: In addition to Sparrow's observations (Sparrow 1936b, 1938), R. marina was observed in the same host from Iceland (Johnson 1966).

Rozella monoblepharidis Cornu, Ann. Sciences Nat., Bot. sér. 5, 15: 150 (1872).

Synonyms: Rozella monoblepharidis-polymorphae Cornu Ann. Sciences Nat., Bot. sér. 5, 15: 150 (1872).

Pleolpidium monoblepharidis-polymorphae (Cornu). A. Fischer, Rabenh. Krypt.-FI. 1 (4): 44 (1892).

Type: Cornu (Ann. Sci. Nat., Bot. sér. 5, 15: pl. 4, figs 13-18, 1872; lectotype designated by Dick 2001: 373).

Description: "Sporangia formed in intercalary swollen parts of the hyphae, ovoid ... with a single small lateral discharge pore; zoospores not observed; resting spore spherical, brown, the thickened wall densely covered with tenuous spines, in intercalary or lateral swellings of the host hyphae, germination not observed" (Sparrow 1960).

Hosts: Monoblepharis polymorpha, and M. macrandra (Monoblepharidomycota).

Rozella multimorpha Letcher \& Longcore, J. Euk. Microbiol. 64: 65: 183 (2018).

Type: Letcher et al. (J. Euk. Microbiol. 65: 182, fig. 1, 2018 - holotype).

Description: Sporangia are monosporangiate, spherical, typically $15-20 \mu \mathrm{m}$ diameter, rarely to $50 \mu \mathrm{m}$ diameter, pyriform, or irregularly-shaped, with (typically) one to three discharge tubes $\sim 2 \mu \mathrm{m}$ diameter x 5-40 $\mu \mathrm{m}$ long, the discharge tube terminating with a constriction and bulb-shaped structure. Zoospores are elongate, 1-1.2 $\mu \mathrm{m}$ diameter x 1.6-1.8 $\mu \mathrm{m}$ long, containing a helmet-shaped nucleus, a microbody-lipid globule complex composed of a single mitochondrion, a pair of lipid globules, a microbody, and a backing membrane. Zoospores are immotile in the sporangium prior to release, and are released as a mass of motile spores that rapidly disperse. Resting spores not observed (Letcher et al. 2018).

Host: Pythium catenulatum (Oomycota).

Rozella parva Canter, Bot. J. Linn. Soc. 62: 275 (1969).

Type: Canter (Bot. J. Linn. Soc. 62: 275, type material IMI 131673 - holotype).

Description: "Sporangium solitary assuming the shape of the unhypertrophied host sporangium or young resting spore. Sporangium usually spherical 4-9.5 $\mu \mathrm{m}$ diameter, with one hyaline dehiscence papilla... Up to 12 zoospores in a sporangium emerging singly on dehiscence and immediately swimming away. Zoospore $2.5 \mu \mathrm{m}$ diameter, sometimes pyriform $1.8 \times$ $3.5 \mu \mathrm{m}$, broad anterior end when swimming. Within the content are two to five anteriorly placed, minute refractive granules; flagellum posterior $12.5 \mu \mathrm{m}$ long, with a short whiplash. Resting spore more or less spherical 5-10.6 $\mu \mathrm{m}$ diameter with a thick refractive wall, on the outside of which may be deposited lumps of solid material, or an apparently thin corrugated undulate external wall. Within the resting spore is a large hyaline sphere and many small refractive globules" (Canter 1969).

Host: Zygorhizidium affluens (Chytridiomycota).

Rozella polyphagi (Sparrow) Sparrow, Mycologia 30: 377 (1938).

Basionym: Pleolpidium polyphagi Sparrow, Trans. Brit. Mycol. Soc. 18: 215 (1933).

Type: Sparrow (J. Linn. Soc., Bot. 50: pl. 14, figs 19-20, 1936; neotype designated by Dick 2001: 374, as "lectotype", drawn from the same material used in Sparrow 1933). 
Description: "Sporangium colorless, spherical, completely filling the often markedly swollen prosporangium of the host, 20-48 $\mu \mathrm{m}$ in diameter, possessing at maturity from two to six prominent papillae 4-8 $\mu \mathrm{m}$ in diameter, through which in innumerable minute posteriorly uniflagellate narrowly ovoid zoospores 2-3 $\mu \mathrm{m}$ long by $1.5-2 \mu \mathrm{m}$ in diameter, with a single globule, are discharged; resting spore not observed (Sparrow 1960).

Host: Polyphagus laevis (Chytridiomycota).

Note: Ultrastructure of the thallus of $R$. polyphagi has been studied (Powell 1984).

Rozella pseudomorpha (Scherff.) Sparrow, Aquatic Phycom.: 124 (1943).

Synonym: Olpidium (?) pseudomorphum Scherff., Arch. Protistenk. 54: 510 (1926).

Type: Scherffel (Arch. Protistenk. 54: taf. 28, figs. 1-5, 1926; lectotype designated here, MBT 384214).

Description: "Sporangium filling the vegetative cell of the host, and hence assuming its shape and size, forming a fairly stout tapering discharge tube; zoospores narrowly ellipsoidal, ovoid, or plump and rod-like, somewhat arched, with from three to five refractive granules, flagellum fairly long, trailing, attached at the concave side of the body, zoospores emerging individually from the discharge tube and remaining for a time near the orifice undergoing amoeboid change in shape, movement hopping; resting spore unknown" (Sparrow 1960).

\section{Host: Lagenidium rabenhorstii (Oomycota).}

Note: Sparrow (1960) stated "that the sporangium fills the vegetative cells of the host". We accept $R$. pseudomorpha here because of the posteriorly uniflagellate zoospore."

Rozella rhipidii Cornu, Ann. Sci. Nat, Bot., sér. 5, 15: 153 (1872).

Synonyms: Rozella rhipidii-spinosi Cornu, Ann. Sci. Nat, Bot., sér. 5, 15: 153 (1872).

Pleolpidium rhipidii-spinosi (Cornu) A. Fischer, Rabenh. Krypt.-FI. 1 (4): 44 (1892).

Pleolpidium araiosporae (Cornu) Minden, Krypt.-Fl. Mark Brandenb. 5: 252 (1911) ["1915"].

Type: Cornu (Ann. Sci. Nat, Bot., sér. 5, 15: 153, pl. 5, figs 1-9, 1872; lectotype designated by Dick 2001: 373).

Description: "Sporangium completely filling the abnormally swollen and obpyriform usually smooth sporangium of the host, with a prominent apical papilla; zoospores variable in shape, reniform, spherical or ellipsoidal, with a long posterior flagellum, discharged through a broad pore, resting a few seconds at the orifice before swimming away; resting spore spherical, yellowish brown or reddish, with dense contents, wall slightly thickened, covered with tenuous spines, germination not observed, predominantly formed in the spiny sporangia of the host" (Sparrow 1960).
Host: Araiospora spinosa (Oomycota).

Rozella rhizoclosmatii Letcher \& Longcore, Fungal Biol. 121: 5 (2017).

Type: Letcher et al. (Fungal Biol. 121: 4, fig. 2E, 2017 holotype).

Description: "Sporangium ... filling host cell and causing hypertrophy of host as indicated by larger size of infected host sporangium ( $45 \mu \mathrm{m}$ av. diameter) relative to that of uninfected host sporangium (15 $\mu \mathrm{m}$ av. diameter). Zoospores motile in the sporangium before they release through a single exit pore. Zoospores oblong or oval, 1-1.3 $\mu \mathrm{m}$ wide $\times 1.8-2$ $\mu \mathrm{m}$ long, with a single posterior flagellum 10-12 $\mu \mathrm{m}$ long. Zoospores have a Rozella-type ultrastructure (Held 1975), plus a lattice of perpendicular rods surrounding the nucleus. Resting spore not observed" (Letcher et al. 2017).

Host: Rhizoclosmatium globosum (Chytridiomycota).

Rozella rhizophlyctidis Karling, Amer. J. Bot. 29: 32 (1942); as "rhizophlyctii".

Type: Karling (Amer. J. Bot. 29: 30, figs 36-47, 1942; lectotype designated by Dick 2001: 375).

Description: "Sporangia solitary, filling host cell and conforming with the latter's size and shape, spherical, 20-110 $\mu \mathrm{m}$, oval, and irregular with 1 to 4 exit papillae which usually project out of the short necks of the host; ... zoospores hyaline, broadly pyriform, $2.5-3 \mu \mathrm{m} \times 1.5-2 \mu \mathrm{m}$, tapering slightly at the anterior end, with a minute globule near the posterior end; posteriorly uniflagellate, ...flagellum 16-18 $\mu \mathrm{m}$ long; swirling in the sporangium before emerging; darting about rapidly in swimming, occasionally becoming amoeboid. Resting spores slightly yellow, oval and spherical, 14-18 $\mu \mathrm{m}$ in diameter, with a large central vacuole and coarsely granular cytoplasm; wall spiny, $1.8 \mu \mathrm{m}$ thick, spines $1.5-2 \mu \mathrm{m}$ long; apparently transformed directly into a zoosporangium in germination and forming zoospores" (Karling 1942a).

Hosts: Rhizophlyctis petersenii, and R. rosea (Chytridiomycota).

Rozella rhizophydii Karling, Mycologia 36: 645 (1944).

Type: Karling (Mycologia 36: 645, figs 20-28, 1944; lectotype designated by Dick 2001: 375).

Description: "Sporangia solitary, filling host cell and conforming with the latter's size and shape, spherical, 15-30 $\mu \mathrm{m}$, oval, $10-12 \mu \mathrm{m} \times 13-20 \mu \mathrm{m}$ or pyriform, $12-15 \mu \mathrm{m} \times$ 16-25 $\mu \mathrm{m}$ with $1-3$ low exit papillae; ...zoospores hyaline, oval or slightly pyriform, $2-2.5 \mu \mathrm{m} \times 3-4 \mu \mathrm{m}$; with a small globule near the posterior end; flagellum 12-14 $\mu \mathrm{m}$ long. Resting spores unknown" (Karling 1944).

Host: Rhizophydium globosum (Chytridiomycota). 
Rozella septigena Cornu, Ann. Sci. Nat., Bot., sér. 5, 15: 163 (1872).

Synonym: Skirgiellia septigena (Cornu) A. Batko, Acta Mycol. 13:322 (1977); nom. Ilegit. (Arts. 52.1, 52.2).

Type: Cornu (Ann. Sci. Nat., Bot. sér. 5: 15: pl. 6, figs. 1-17, 1872).

Description: "Sporangia possibly formed by successive fractionation of one thallus, in transversely or obliquely walled-off segments of the sometimes slightly swollen host hyphae which they completely fill, with from one to several discharge papillae; zoospores minute, numerous, arched, posteriorly uniflagellate, without globules; resting spore spherical, with a slightly thickened wall covered with short tenuous spines, brownish, with dense contents, formed in spherically swollen short lateral branches of the hyphae, which are continuous with the main axis or separated from it by a cross wall, germination not observed" (Sparrow 1960).
Hosts: Achyla, Saprolegnia (Oomycota).

Note: This species was designated as the type of the genus by Clements \& Shear 1931: 234). "Cornu's name was applied, in error, by Fischer (1882: 365$)$ to a similar-appearing parasite in Saprolegnia which forms biflagellate zoospores" (Sparrow 1960).

\section{Doubtful and excluded species}

Rozella barrettii Karling, Mycologia 34: 202 (1942).

"Based on an incompletely known form described by Barrett (1934: 1138). Since the flagellation of the zoospores is not known, the fungus cannot be placed generically" (Sparrow 1960: 180).

Rozella maxima Karling, Amer. J. Bot. 29: 24 (1942); as "maximum".

Apparently a typographical error for R. marina (q.v.).

\section{KEY TO THE SPECIES OF ROZELLA}

Host: Lagenidium

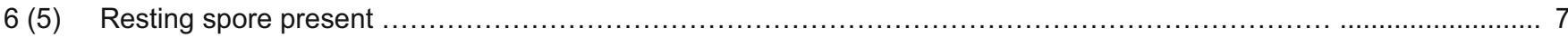

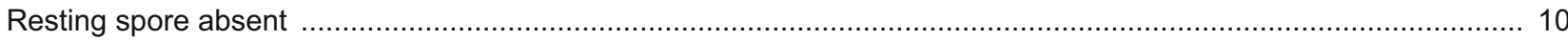

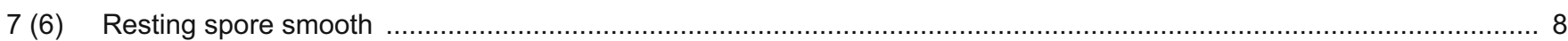

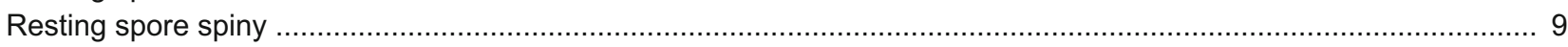

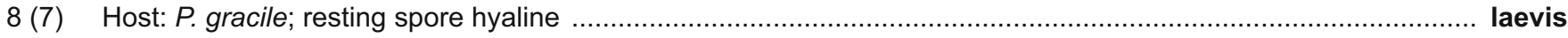
Host: $P$. intermedium, $P$. monospermum; resting spore pale yellow .......................................................... cuculus

9 (7) Host: $P$. vexans; resting spore pale yellow irregularis Host: Pythium sp., resting spore dark brown 
11 (4) Host: Diplophlyctis diplophlyctidis Host: Rhizophlyctis rhizophlyctidis Host: Chytriomyces chytriomycetis Host: Polyphagus polyphagi Host: Endochytrium endochytrii Host: Cladochytrium, Nowakowskiella cladochytrii Host: Rhizophydium rhizophydii Host: Zygorhizidium parva Host: Rhizoclosmatium rhizoclosmatii Host: Chytridium canterae

Host: Algochytrops marina

\section{ACKNOWLEDGEMENTS}

This study was supported by the National Science Foundation through MRI DEB-0500766 and DEB-1455611. We very much appreciate Shaun Pennycook (Landcare Research, New Zealand) for his assistance with nomenclatural issues.

\section{REFERENCES}

Adl SM, Simpson AGB, Farmer MA, Andersen RA, Anderson OR, Barta JR, et al. (2005) The new higher level classification of eukaryotes with emphasis on the taxonomy of protists. Journal of Eukaryotic Microbiology 52: 399-451.

Barr DJS, Bandoni R (1979) A new species of Rozella on a basidiomycete. Mycologia 71: 1261-1264.

Bass D, Czech L, Williams BAP, Berney C, Dunthorn M, et al. (2018) Clarifying the relationships between Microsporidia and Cryptomycota. Journal of Eukaryotic Microbiology: doi: 10.1111/ jeu.12519.

Batko A (1977) Further observations on Nellymyces megaceros and its parasite - Rozellopsis uliginosa sp. nov. Acta Mycologica. 13: 313-324.

Barrett JT (1934) A chytridiaceous parasite of Phytophthora. Phytopathology 24: 1138

Blackwell WH, Letcher PM, Powell MJ (2016) Reconsideration of the inclusiveness of the genus Plasmophagus (Chytridiomycota, posteris traditus) based on morphology. Phytologia 98: 128-136.

Brown MW, Spiegel FW, Silberman JD (2009) Phylogeny of the "forgotten" cellular slime mold, Fonticula alba, reveals a key evolutionary branch within Opisthokonta. Molecular Biology and Evolution 26: 2699-2709.

Butler EJ (1907) An account of the genus Pythium and some Chytridiaceae. Memoirs of the Department of Agriculture, India, Botany 1: 1-160.

Canter HM (1950) Studies on British chytrids. XI. Chytridium oedogonii Couch. Transactions of the British Mycological Society 33: 354-358.

Canter HM (1969) Studies on British chytrids. XXIX. A taxonomic revision of certain fungi found on the diatom Asterionella. Botanical Journal of the Linnean Society 62: 267-278.

Cavalier-Smith T (1987) The origin of Fungi and pseudofungi. In: Evolutionary Biology of the Fungi (Rayner AD, Brasier CM, Moore D, eds): 339-353. Cambridge: Cambridge University Press.

Cavalier-Smith, T, Chao, EE (1995) The opalozoan Apusomonas is related to the common ancestor of animals, fungi and choanoflagellates. Proceedings of the Royal Society of London, B 261: 1-6.
Clements FE, Shear CL (1931) The Genera of Fungi. New York: H.W. Wilson.

Corliss JO, Levine ND (1963) Establishment of the Microsporidea as a new class in the protozoan subphylum Cnidospora. Journal of Protozoology 10 (Suppl.): 26-27.

Cornu M (1872) Monographie des Saprolégniées: étude physiologique et systématique. Annales des Sciences Naturelle, Botanique, sér. 5, 15: 1-198.

Corsaro D, Walochnik J, Venditti D, Steinmann J, Müller K-D, Michel R (2014) Microsporidia-like parasites of amoebae belong to the early fungal lineage Rozellomycota. Parasitology Research: doi: 10.1007/s00436-014-3838-4

Dick MW (2001) Staminipilous fungi: systematics of the Peronosporomycetes including accounts of the marine straminipilous protists, the plasmodiophorids and similar organisms. Dordrecht: Kluwer Academic Publishers.

Doweld A (2013) Nomenclatural novelties. Rozellomycota. Index Fungorum 43: 1.

Doweld A (2014) Nomenclatural novelties. Skirgiellia achlyae, Skirgiellia allomycetis, and Skirgielliaceae. Index Fungorum 129: 1.

Fischer A (1882) Untersuchungen über die Parasiten der Saprolegnieen. Jahrbücher für wissenschaftliche Botanik 13 286-371.

Fischer A (1892) Phycomycetes. Rabenhorst's Kryptogamen-Flora 1 (4): 1-490.

Foust FK (1937) A new species of Rozella parasitic on Allomyces. Journal of the Elisha Mitchell Scientific Society 53: 197-204.

Grossart H-P, Wurzbacher C, James TY (2016) Discovery of dark matter fungi in aquatic ecosystems demands a reappraisal of the phylogeny and ecology of zoosporic fungi. Fungal Ecology 19: 28-38.

Held AA (1972a) Host-parasite relations between Allomyces and Rozella. Archiv für Mikrobiologie 82: 128-139.

Held AA (1972b) Improved culture methods for Rozella and for Olpidiopsis. Mycologia 64: 871-886.

Held AA (1973a) Encystment and germination of the parasitic chytrid Rozella allomycis on host hyphae. Canadian Journal of Botany 51: 1825-1835.

Held AA (1973b) The Torrey Symposium on current aspects of fungal development. III. Development of endoparasitic, zoosporic fungi. Bulletin of the Torrey Botanical Club 100: 203-216.

Held AA (1974) Attraction and attachment of zoospores of the parasitic chytrid Rozella allomycis in response to host-dependent factors. Archiv für Mikrobiologie 95: 97-114.

Held AA (1975) The zoospore of Rozella allomycis: ultrastructure. Canadian Journal of Botany 53: 2212-2232.

Held AA (1980) Development of Rozella in Allomyces: a single 
zoospore produces numerous zoosporangia and resistant sporangia. Canadian Journal of Botany 58: 959-979.

Held AA (1981) Rozella and Rozellopsis: naked endoparasitic fungi which dress-up as their hosts. Botanical Review 47: 451-515.

James TY, Berbee ML (2011) No jacket required - a new fungal lineage defies dress code. BioEssays 34: 94-102.

James TY, Letcher PM, Longcore JE, Mozley-Standridge SE, Porter D, et al. (2006) A molecular phylogeny of the flagellated fungi (Chytridiomycota) and description of a new phylum (Blastocladiomycota). Mycologia 98: 860-871.

James TY, Pelin A, Bonen L, Ahrendt S, Sain D, et al. (2013) Shared signatures of parasitism and phylogenomics unite Cryptomycota and Microsporidia. Current Biology 23: 1548-53.

Johnson TW (1955) Inoculation studies with a polysporangiate Rozella parasitic in Dictyuchus anomalus. American Journal of Botany 42: 119-123.

Johnson TW (1966) Rozella marina in Chytridium polysiphoniae from Icelandic waters. Mycologia 58: 490-494.

Jones MDM, Forn I, Gadelha C, Egan MJ, Bass D, et al. (2011a) Discovery of novel intermediate forms redefines the fungal tree of life. Nature 474: 200-203.

Jones MDM, Richards TA, Hawksworth DL, Bass D (2011b) Validation and justification of the phylum name Cryptomycota phyl. nov. IMA Fungus 2: 173-175.

Karling JS (1941) Texas chytrids. Torreya 41: 105-108.

Karling JS (1942a) Parasitism among the chytrids. American Journal of Botany 29: 24-35.

Karling JS (1942b) A synopsis of Rozella and Rozellopsis. Mycologia 34: 193-208.

Karling JS (1944) Brazilian chytrids. IV. Species of Rozella. Mycologia 36: $638-647$.

Karling JS (1946) Two new chytrid parasites of Chytriomyces. Mycologia 38: 103-109.

Karling JS (1965) Some zoosporic fungi of New Zealand. I. Sydowia 19: 213-226.

Karling JS (1977) Chytridiomycetarum Iconographia. Monticello, NY: Lubrecht \& Cramer.

Karling JS (1981) Rozella irregularis (?) Butler and some other zoosporic fungi from China. Nova Hedwigia 34: 633-644.

Karling JS (1987) Ross biological reserve aquatic fungi III. Additional species. Nova Hedwigia 45: 529-535.

Karpov SA, Mamkaeva MA, Aleoshin VV, Nassonova E, Lilje O, Gleason FH (2014) Morphology, phylogeny, and ecology of the aphelids (Aphelidea, Opisthokonta) and proposal for the new superphylum Opisthosporidia. Frontiers in Microbiology 5 (112): 1-11.

Karpov SA, Torruella G, Moreira D, Mamkaeva MA, López-García (2017) Molecular phylogeny of Paraphelidium letcheri sp. nov. (Aphelida, Opisthosporidia). Journal of Eukaryotic Microbiology 64: 573-578.

Lara E, Moriera D, López-Garcia P (2010) The environmental clade LKM11 and Rozella form the deepest branching clade of fungi. Protist 161: 116-121.

Lazarus KL, James TY (2015) Surveying the biodiversity of the Cryptomycota using a targeted PCR approach. Fungal Ecology 14: $62-70$.

Letcher PM, Longcore JE, Quandt CA, Leite DS, James TY, Powell MJ (2017) Morphological, molecular and ultrastructural characterization of Rozella rhizoclosmatii, a new species in Cryptomycota. Fungal Biology 121: 1-10.
Letcher PM, Longcore JE, James TY, Leite DS, Simmons DR, Powell MJ (2018) Morphology, ultrastructure, and molecular phylogeny of Rozella multimorpha, a new species in Cryptomycota. Journal of Eukaryotic Microbiology 65: 180-190.

Liu Y, Steenkamp T, Brinkman H, Forget L, Philippe H, Lang BF (2009) Phylogenomic analyses predict sistergroup relationship of nucleariids and Fungi and paraphyly of zygomycetes with significant support. BMC Evolutionary Biology 9: 272, doi:10.1186/1471-2148-9-272.

Minden, M von (1911) [“1915"] Chytridiineae, Ancylistineae, Monoblepharidineae, Saprolegniineae. Kryptogamen Flora de Mark Brandenburg 5 (2): 193-352.

Nabel K (1939) Über die Membran niederer Pilze, besonders von Rhizidiomyces bivellatus nov. spez. Archiv für Mikrobiology 10: 515-541.

Powell MJ (1984) Fine structure of the unwalled thallus of Rozella polyphagi in its host Polyphagus euglenae. Mycologia 76: 10391048.

Powell MJ, Letcher PM, James TY (2017) Ultrastructural characterization of the host-parasite interface between Allomyces anomalus (Blastocladiomycota) and Rozella allomycis (Cryptomycota). Fungal Biology 121: 561-572.

Rojas-Jimenez K, Wurzbacher C, Bourne EC, Chiuchiolo A, Priscu JC, Grossart H-P (2017) Early diverging lineages within Cryptomycota and Chytridiomycota dominate the fungal communities in ice-covered lakes of the McMurdo Dry Valleys, Antarctica. Scientific Reports 7: 15348, doi:10.1038/s41598017-15598-w.

Scherffel A (1926) Beiträge zur Kenntnis der Chytridineen. Teil III. Archiv für Protistenkunde 54: 510-528.

Shanor L (1942)A new Rozella of the polysporangiate series. Jouirnal of the Elisha Mitchell Scientific Society 58: 99-101.

Shen SC, Siang WN (1948) Studies in the aquatic phycomycetes of China. Science Reports of National Tsing Hua University, Ser. B, Biological and Psychological Sciences 3: 179-203.

Sparrow FK (1933) New chytridiaceous fungi. Transactions of the British Mycological Society 18: 215-217.

Sparrow FK (1936a) A contribution to our knowledge of the aquatic phycomycetes of Great Britain. Journal of the Linnean Society, Botany 50: 417-478.

Sparrow FK (1936b) Biological observations on the marine fungi of Woods Hole waters. Biological Bulletin 70: 236-263.

Sparrow FK (1938) Remarks on the genus Rozella. Mycologia 30 : 375-378.

Sparrow FK (1943) Aquatic Phycomycetes. Ann Arbor, MI: University of Michigan Press.

Sparrow FK (1960) Aquatic Phycomycetes. $2^{\text {nd }}$ edn. Ann Arbor, MI: University of Michigan Press.

Sparrow FK, Paterson RA, Johns RM (1965) Additions to the phycomycetes flora of the Douglas Lake Region. V. New or interesting fungi. Papers of the Michigan Academy of Sciences 50: 115-123.

Tedersoo L, Bahram M, Puusepp R, Nilsson RH, James TY (2017) Novel soil-inhabiting clades fill gaps in the fungal tree of life. Microbiome: doi10.1186/s40168-017-0259-5

Tedersoo L, Sánchez-Ramírez S, Köljalg U, Bahram M, Döring M, et al. (2018) High-level classification of the fungi and a tool for evolutionary ecological analyses. Fungal Diversity 90: 135-159.

Turland NJ, Wiersema JH, Barrie FR, Greuter W, Hawksworth DL, 
et al. (eds) (2018) International Code of Nomenclature for algae, fungi, and plants (Shenzhen Code) adopted by the Nineteenth International Botanical Congress Shenzhen, China, July 2017.

[Regnum Vegetabile no. 159.] Glashütten: Koeltz Botanical Books.

Willoughby LG, Rigg E (1983) Lower aquatic fungi in the soils of Majorca. Nova Hedwigia 37: 369-383. 